\title{
PERLINDUNGAN HUKUM TERHADAP NOTARIS YANG AKTA OTENTIKNYA BERINDIKASI SEBAGAI ALAT PENCUCIAN UANG
}

\author{
Windi \\ Magister Kenotariatan Fakultas Hukum Universitas Brawijaya \\ J1. Veteran, Malang Jawa Timur 65145, Indonesia. \\ Email: elastutiwindi@gmail.com
}

\begin{abstract}
The purpose of this study is to describe the responsibility of a notary to a deed made in the future proved to be a money laundering tool and to describe the legal protection for a notary against authentic deeds made when in the future proved to be a money laundering tool. This research is normative juridical. Juridical because in examining the problems studied through the research material through literature study to obtain secondary data. Normative because this research is based on literature research to get the material relevant to the research problem. The results of this study The responsibility of a Notary whose authentic deed is proven as a money laundering tool is a Notary must be held accountable for his actions with civil sanction in the form of reimbursement of costs or compensation to the injured party for unlawful acts committed by Notary. However, before Notary is sanctioned by civil law, Notary must first be proven that there has been a loss caused by the action against Notary's law against the parties, and between the loss suffered and the unlawful act of Notary there is a causal relationship, and the action against the law or negligence Due to errors that can be accountable to the Notary concerned. Form of legal protection for the Notary to the deeds he made when indicated money laundering in civil cases is the existence of independent Notary Publicity Council, in this case the existence of MKN is not a sub-part of the government that raised it.
\end{abstract}

Keywords: Legal protection, Notary Public, Money laundering 


\begin{abstract}
ABSTRAK
Tujuan dari penelitian ini adalah untuk mendeskripsikan tanggung jawab notaris terhadap akta yang dibuat apabila dikemudian hari ternyata terbukti sebagai alat pencucian uang dan mendeskripsikan perlindungan hukum bagi notaris terhadap akta otentik yang dibuat apabila dikemudian hari ternyata terbukti sebagai alat pencucian uang. Penelitian ini bersifat yuridis normatif. Yuridis karena dalam menelaah permasalahan dikaji atas materi penelitian melalui telaah kepustakaan untuk memperoleh data sekunder. Normatif karena penelitian ini berdasarkan pada penelitian kepustakaan guna mendapatkan bahan yang relevan dengan permasalahan penelitian. Hasil penelitian ini Tanggung jawab Notaris yang akta otentiknya terbukti sebagai alat pencucian uang adalah Notaris wajib mempertanggungjawabkan perbuatannya dengan dijatuhi sanksi perdata berupa penggantian biaya atau ganti rugi kepada pihak yang dirugikan atas perbuatan melawan hukum yang dilakukan oleh Notaris. Namun sebelum Notaris dijatuhi sanksi perdata maka Notaris terlebih dahulu harus dapat dibuktikan bahwa telah adanya kerugian yang ditimbulkan dari perbuatan melawan hukum Notaris terhadap para pihak, dan antara kerugian yang diderita dan perbuatan melawan hukum dari Notaris terdapat hubungan kausal, serta perbuatan melawan hukum atau kelalaian tersebut disebabkan kesalahan yang dapat dipertanggungjawabkan kepada Notaris yang bersangkutan.Bentuk perlindungan hukum bagi Notaris terhadap akta-akta yang dibuatnya apabila terindikasi pencucian uang secara perdata adalah adanya Majelis Kehormatan Notaris yang bersifat independen, dalam hal ini keberadaan MKN tidak merupakan sub bagian dari pemerintah yang mengangkatnya.
\end{abstract}

Kata Kunci : Perlindungan hukum, Notaris, Pencucian uang 


\section{A. PENDAHULUAN}

\section{Latar Belakang Masalah}

Profesi notaris serta pejabat yang membuat akta tanah mempunyai tugas untuk melayani seluruh lapisan masyarakat dalam bidang keperdataan seharusnya tidak dijadikan sebagai sarana pencucian uang oleh para pelaku tindak pidana. Dengan masuknya Pejabat Pembuat Akta Tanah dan notaris sebagi pelapor atas transaksi yang terindikasi tindak pidana maka secara tidak langsung keduanya mempunyai peran secara langsung dalam mewujudkan negara yang damai, bersih, dan sejahtera.

Selain itu secara langsung laporan yang dilakukan oleh Pejabat Pembuat Akta Tanah dan notaris membawa dampak baik bagi Pejabat Pembuat Akta Tanah dan notaris itu sendiri. Dampak baik itu pertama adalah laporan yang dilaksanakan oleh Pejabat Pembuat Akta Tanah dan notaris dapat mengembalikan citra Pejabat Pembuat Akta Tanah dan notaris yang selama ini terlanjur dianggap buruk oleh masyarakat. Selain itu dampak baik yang secara nyata dirasakan oleh Pejabat Pembuat Akta Tanah dan notaris yang digolongkan sebagai pihak yang melaporkan adalah adanya suatu jaminan hukum dari pemerintah karena dalam pasal 29 Undang-undang tindak pidana pencucian uang mengatakan bahwa pihak pelapor dalam menjalankan tugas dan kewajibannya tidak dapat dituntut baik secara pidana maupun perdata kecuali di dalamnya terdapat unsur disengaja dalam hal menyalahgunakan wewenangnya.

\section{Rumusan Masalah}

a. Bagaimana tanggung jawab notaris terhadap akta yang dibuat apabila dikemudian hari ternyata terbukti sebagai alat pencucian uang

b. Bagaimana perlindungan hukum bagi notaris terhadap akta otentik yang dibuat apabila dikemudian hari ternyata terbukti sebagai alat pencucian uang. 


\section{Tujuan Penelitian}

a. Untuk mengkaji secara mendalam tanggung jawab notaris terhadap akta yang dibuat apabila dikemudian hari ternyata terbukti sebagai alat pencucian uang

b. Untuk mengkaji secara mendalam perlindungan hukum bagi notaris terhadap akta otentik yang dibuat apabila dikemudian hari ternyata terbukti sebagai alat pencucian uang.

\section{B. PEMBAHASAN}

\section{Unsur-unsur Tindak Pencucian Uang dengan Akta Otentik}

Berdasarkan Perumusan unsur-unsur pidana dari bunyi Pasal 263 KUHP mengenai pemalsuan akta otentik yang dilakukan oleh Notaris tidak bisa diterapkan kepada pelaku yakni Notaris yang memalsu akta otentik. Akan tetapi Notaris tersebut dapat dikenakan sanksi dari Pasal 264 KUHP, sebab Pasal 264 KUHP merupakan Pemalsuan surat yang diperberat dikarenakan obyek pemalsuan ini mengandung nilai kepercayaan yang tinggi. Sehingga semua unsur yang membedakan antara Pasal 263 dengan Pasal 264 KUHP hanya terletak pada adanya obyek pemalsuan yaitu "Macam surat dan surat yang mengandung kepercayaan yang lebih besar akan kebenaran isinya". ${ }^{19}$

Notaris dapat dikenakan sanksi Pasal 264 KUHP apabila terbukti telah melakukan pemalsuan akta otentik. Pasal 264 merumuskan sebagai berikut :

Menjelaskan bahwa pemalsuan surat diancam dengan pidana penjara paling lama delapan (8) tahun jika dilakukan terhadap:

a. Akta Otentik.

b. Surat hutang dan sertifikat hutang dari suatu negara atau bagiannya ataupun dari suatu lembaga umum.

\footnotetext{
${ }^{19}$ Adamichazawi, Op.Cit, hal. 107
} 
c. Surat sero atau hutang atau sertifikat sero atau hutang dari suatu perkumpulan, yayasan, perseroan atau maskapai.

d. Talon, tanda bukti deviden atau bunga dari salah satu surat yang diterangkan dalam 2 dan 3 atau tanda bukti yang dikeluarkan sebagai pengganti surat-surat itu.

e. Surat kredit atau surat dagang yang disediakan untuk diedarkan.

Diancam dengan pidana yang sama barang siapa yang sengaja memakai surat tersebut dalam ayat pertama, yang isinya tidak sejati atau yang dipalsukan seolah-olah benar dan tidak dipalsu jika pemalsuan surat itu dapat menimbulkan kerugian. Nyatalah bahwa yang menyebabkan diperberatnya pemalsuan surat Pasal 264 diatas terletak pada faktor macam-macamnya surat. Surat-surat tertentu yang menjadi objek kejahatan adalah surat-surat yang mengandung kepercayaan yang lebih besar akan kebenaran isinya. Pada suratsurat itu mempunyai derajat kebenaran yang lebih tinggi dari pada surat-surat biasa atau surat-lainnya. Kepercayaan yang lebih besar terhadap kebenaran akan isi dari macam-macam surat itulah yang menyebabkan di perberat ancaman pidananya.

Penyerangan terhadap kepercayaan masyarakat yang lebih besar terhadap isi surat-surat yang demikian dianggap membahayakan kepentingan umum masyarakat yang lebih besar pula. Ada 2 kejahatan yang dirumuskan dalam Pasal 264 yang masing-masing dirumuskan dalam ayat (1) dan (2). Kejahatan pada ayat (1) mempunyai unsur-unsur sebagai berikut :

a. Semua unsur baik obyektif maupun subyektif Pasal 263.

b. Unsur-unsur khusus pemberatnya (bersifat alternatif) berupa obyek surat-surat tertentu, ialah :

1) Akta otentik.

2) Surat hutang dan sertifikat hutang dari suatu negara atau bagiannya ataupun dari suatu lembaga umum 
3) Surat sero atau hutang atau sertifikat sero atau hutang dari suatu perkumpulan, yayasan, perseroan atau maskapai

4) Talon, tanda bukti deviden atau bunga dari salah satu surat yang diterangkan dalam 2 dan 3 atau tanda bukti yang dikeluarkan sebagai pengganti surat-surat itu.

5) Surat kredit atau surat dagang yang disediakan untuk diedarkan. Sedangkan Unsur-unsur kejahatan dalam ayat (2) adalah sebagai berikut:

c. Unsur-unsur obyektif:

1) Perbuatan: Memakai.

2) Obyeknya: surat-surat tersebut pada ayat (1) :

3) Pemakaian itu seolah-olah isinya benar dan tidak dipalsu.

d. Unsur Subyektif: dengan sengaja.

Sebagaimana diatas telah diterangkan bahwa akta otentik itu dibuat oleh pejabat umum yang menurut Undang-Undang berwenang untuk membuatnya, misalnya seorang Notaris, Pegawai Catatan Sipil, Pejabat Pembuat Akta Tanah (PPAT). Pejabat ini dalam pembuatan suatu akta otentik adalah memenuhi permintaan. Orang yang meminta inilah yang dimaksud orang yang menyuruh memasukkan keterangan palsu. Perbuatan menyuruh memasukkan mengandung unsur-unsur :

a. Inisiatif atau kehendak untuk membuat akta, akta mana memuat tentang apa (Obyek yakni: mengenai sesuatu hal atau kejadian) yang disuruuh masukkan kedalamnya adalah berasal dari orang-orang yang memasukkan, bukan dan pejabat pembuat akta otentik.

b. Dalam hubungannya dengan asalnya inisiatif dari orang yang meminta dibuatkannya akta otentik, maka dalam perkataan/unsur menyuruh memasukkan berarti orang itu dalam kenyataannya ia memberikan keterangan-keterangan tentang sesuatu hal, hal mana adalah bertentangan dengan kebenaran atau palsu. 
c. Pejabat pembuat akta otentik tidak mengetahui bahwa keterangan yang disampaikan oleh orang yang menyuruh memasukkan keterangan kepadanya itu adalah keterangan yang tidak benar.

d. Oleh karena pejabat pembuat akta otentik tidak mengetahui perihal tidak benarnya keterangan tentang sesuatu hal itu, maka ia tidak dapat dipertanggungjawabkan, terhadap perbuatannya yang melahirkan akta otentik yang isinya palsu itu, dan karenanya ia tidak dapat dipidana. ${ }^{116}$

Unsur kesalahan dalam kejahatan Pasal 266 (1) KUHP adalah dengan maksud untuk memakai akta yang memuat kejadian palsu yang demikian itu seolah-olah keterangan dalam kata itu sesuai dengan kebenaran. Mengenai unsur kesalahan ini pada dasamya sama dengan unsur kesalahan dalam Pasal 263 (1) KUHP yang sudah diterangkan dibagian muka. Demikian juga mengenai unsur "Jika pemakaian itu menimbulkan kerugian, sudah diterangkan secara cukup dalam pembicaraan terhadap Pasal 263 dan 264 KUHP.

Notaris bisa saja dihukum pidana, jika dapat dibuktikan dipengadilan, bahwa secara sengaja Notaris bersama-sama dengan para pihak/penghadap untuk membuat akta dengan maksud dan tujuan untuk menguntungkan pihak atau penghadap dengan cara merugikan pihak penghadap yang lain. Jika hal ini terbukti maka pihak penghadap yang merugikan pihak lain beserta Notaris tersebut wajib dihukum.

Notaris dalam melaksanakan jabatannya sebagai pejabat umum yang membuat akta otentik sebenamya berada diantara mungkin/tidak mungkin melakukan pemalsuan akta dengan pihak yang menghadap untuk meminta dibuatkan aktanya. Dikarenakan apabila seorang notaris selaku pejabat umum tidak lagi menjunjung tinggi tentang Etika profesinya/tidak lain menyimpang dari peraturan hukum Undang-Undang Jabatan Notaris (UU Perubahan atas UUJN) dengan alasan ingin menguntungkan salah satu pihak tersebut untuk 
ikut peran serta membantu para pihak lainnya dan sebaliknya sehingga lahirlah akta yang mengandung keterangan palsu.

Notaris dapat dikatakan melakukan perbuatan melawan hukum dalam konteks Hukum Pidana sekaligus juga melanggar kode etik dan UU Perubahan atas UUJN, sehingga syarat pemidanaan menjadi lebih kuat. Apabila hal tersebut tidak disertai dengan pelanggaran kode etik atau bahkan dibenarkan oleh UU Perubahan atas UUJN, maka mungkin hal ini dapat menghapuskan sifat melawan hukum suatu perbuatan dengan suatu alasan pembenar. Adapun pemidanaan terhadap Notaris dapat saja dilakukan dengan batasan sebagai berikut :

a. Ada tindakan hukum dari Notaris terhadap aspek formal akta yang sengaja, penuh kesadaran dan keinsyafan serta direncanakan, bahwa akta yang dibuat dihadapan Notaris atau oleh Notaris bersama-sama (sepakat) untuk dijadikan dasar untuk melakukan suatu tindak pidana.

b. Ada tindakan hukum dari Notaris dalam membuat akta di hadapan atau oleh Notaris yang jika diukur berdasarkan UU Perubahan atas UUJN tidak sesuai dengan UU Perubahan atas UUJN.

c. Tindakan Notaris tersebut tidak sesuai menurut instansi yang berwenang untuk menilai tindakan suatu Notaris, dalam hal ini MPN. $^{20}$

\section{Tanggung Jawab Pidana Notaris}

Terjadinya suatu pelanggaran terhadap ketentuan Pasal 15 dan 16 UU Perubahan atas UUJN oleh Notaris di dalam menjalankan jabatannya sangatrentan terhadap kemungkinan terjadinya perbuatan pemalsuan atas akta yang dibuat dihadapan oleh para pihak (penghadap). Akan tetapi perbuatan Notaris tersebut sangat sulit untuk membuktikannya. Hal ini mengingat bahwa

\footnotetext{
${ }^{20}$ Habib Adjie I, Op.Cit, hal. 124-125
} 
di dalam akta Notaris selalu disebutkan pada awal akta bahwa penghadap menghadap pada Notaris dan pada akhir akta selalu disebutkan bahwa akta tersebut dibacakan oleh Notaris kepada para penghadap dan saksi dihadapan Notaris. Namun dalam kenyataannya baik pembacaan dan penandatanganan tidak pernah dilakukan dihadapan Notaris sebagaimana dimaksud ketentuan Pasal 16 ayat (1) huruf k UU Perubahan atas UUJN, maka Notaris dianggap telah melakukan pelanggaran membuat akta palsu sebagaimana dimaksud Pasal 263, Pasal 264 dan Pasal 266 KUHP. Akan tetapi untuk menyatakan tentang adanya kebenaran Notaris melakukan perbuatan tersebut tentu harus melalui proses pembuktian yang dalam sistem pembuktian acara pidana disebut dengan sistem negatif yaitu suatu sistem pembuktian dengan mencari kebenaran materiil yaitu seorang hakim dalam suatu sistem pembuktian di depan pengadilan agar suatu pidana dapat dijatuhkan harus memenuhi dua syarat mutlak meliputi adanya alat bukti yang cukup dan keyakinan hakim. ${ }^{21}$

Notaris yang terbukti melakukan perbuatan melawan hukum dalam menjalankan profesinya wajib mempertanggungjawabkan perbuatan yang dilakukannya tersebut. Besarnya tanggung jawab Notaris dalam menjalankan profesinya mengharuskan Notaris untuk selalu cermat dan hati-hati dalam setiap tindakannya.

Sedangkan dalam teori keadilan menurut Hans Kelsen yang menyatakan bahwa hukum sebagai tatanan sosial yang dapat dinyatakan adil apabila dapat mengatur perbuatan manusia dengan cara yang memuaskan sehingga dapat menemukan kebahagian didalamnya. Dari teori tersebut dapat dijelaskan bahwa tujuan dari pertanggungjawaban seorang Notaris yaitu untuk memberikan rasa adil bagi para pihak maupun bagi Notaris sebagai akibat dan perbuatan melawan hukum seorang Notaris dalam pembuatan akta otentik.

${ }^{21}$ Munir Fuady, 2006, Teori Hukum Pembuktian (Pidana dan Perdata), Citra Aditya Bakti, Bandung, hal. 2 


\section{Tanggung Jawab Notaris}

Bidang Hukum Perdata temtama untuk membuat alat bukti otentik (akta Notaris). Dalam pembuatan akta Notaris baik dalam bentuk partij akta maupun relaas akta, Notaris bertanggungjawab supaya setiap akta yang dibuatnya mempunyai sifat otentik sebagaimana yang dimaksud dalam Pasal 1868 KUHPerdata. Kewajiban Notaris untuk dapat mengetahui peraturan hukum yang berlaku di Negara Indonesia juga serta untuk mengetahui hukum apa yang berlaku terhadap para pihak yang datang kepada Notaris untuk membuat akta. Hal tersebut sangat penting agar supaya akta yang dibuat oleh Notaris tersebut memiliki otentisitasnya sebagai akta otentik karena sebagai alat bukti yang sempurna. Namun dapat saja Notaris melakukan suatu kesalahan dalam pembuatan akta. Kesalahan-kesalahan yang mungkin dapat terjadi, yaitu :

a. Kesalahan ketik pada salinan Notaris, dalam hal ini kesalahan tersebut dapat diperbaiki dengan membuat salinan baru yang sama dengan yang asli dan hanya salinan yang sama dengan yang asli baru mempunyai kekuatan sama seperti akta asli.

b. Kesalahan bentuk akta Notaris, dalam hal ini dimana seharusnya dibuat belita acara rapat tapi oleh Notaris dibuat sebagai pernyataan keputusan rapat.

c. Kesalahan isi akta Notaris, dalam hal ini mengenai keterangan dari para pihak yang menghadap Notaris, di mana saat pembuatan akta dianggap benar tapi ternyata kemudian tidak benar. Apabila ada akta Notaris dipermasalahkan oleh para pihak atau yang berkepentingan, maka untuk menyelesaikannya harus didasarkan pada kebatalan dan pembatalan akta Notaris sebagai suatu alat bukti yang sempurna. Kesalahan-kesalahan yang terjadi pada akta-akta yang dibuat oleh 
Notaris akan dikoreksi oleh hakim pada saat akta Notaris tersebut diajukan ke pengadilan sebagai alat bukti. ${ }^{22}$

Dalam hal suatu akta Notaris dibatalkan oleh putusan hakim di pengadilan, maka jika menimbulkan kerugian bagi para pihak yang berkepentingan, Notaris dapat dituntut untuk rnemberikan ganti rugi, sepanjang hal tersebut terjadi disebabkan oleh karena kesalahan Notaris. Namun dalam hal pembatalan akta Notaris oleh pengadilan dengan alasan bukan merupakan kesalahan Notaris, maka para pihak yang berkepentingan tidak dapat menuntut Notaris untuk memberikan ganti rugi. ${ }^{23}$

Seorang Notaris baru dapat dikatakan bebas dari pertanggungjawaban hukum apabila akta otentik yang dibuatnya dan atau dibuat dihadapannya telah memenuhi syarat formil. Akibat hukum terhadap perbuatan melawan hukum yang dilakukan oleh Notaris dalam pembuatan akta otentik pada dasarnya terjadinya suatu perkara dimana pejabat umum telah mencari-cari keuntungan serta menyalahgunakan kewenangan yang telah diatur dalam UU Perubahan atas UUJN dan seorang klien atau penghadap lainnya merasa dimgikan atas terbuatnya suatu akta yang mengandung unsur perbuatan melawan hukum yang dilakukan oleh Notaris, sehingga berakibat akta otentik yang dibuat oleh Notaris dapat menjadi batal atau dapat dibatalkan.

\section{Perlindungan Hukum Bagi Notaris}

Notaris sebagai manusia, secara kodrati dapat melakukan kesalahankesalahan baik yang bersifat pribadi maupun yang menyangkut profesionalitas dalam menjalankan tugas jabatannya. Notaris tidak jarang digugat oleh para pihak atau kliennya karena merasa tidak puas atau merasa dirugikan sebagai akibat dari akta otentik yang dibuat oleh Notaris. Dalam hal ini Notaris sering

\footnotetext{
${ }^{22}$ Mudofr Hadi, 1991, Varia Peradilan Tahun VI Nomor 72, Pembatalan Isi Akta Notaris Dengan Putusan Hakim, hal. 142-143.

${ }^{23}$ George Whitecross Patton, 1953, A Text-Book af Jurisprudence, Oxford at the Clarendon Press, second editon, hlm. 481
} 
digugat secara perdata maupun secara pidana karena Notaris tersebut diduga telah melakukan kesalahan (malpraktek) dalam menjalankan tugas jabatannya sebagai pejabat umum dalam membuat akta otentik. Dalam menanggapi segala bentuk tuntutan atau gugatan dari para pihak atau klien tersebut, harus dilihat kembali kedudukan akta Notaris sebagai akta otentik yang mempunyai kekuatan pembuktian yang sempurna. Apabila dalam hal ini ada pihak yang menyangkal kebenaran akta Notaris tersebut, maka pihak yang menyangkal tersebut harus dapat membuktikan ketidakbenaran dari akta Notaris tersebut.

Undang-Undang Jabatan Notaris telah mengatur bentuk perlindungan hukum yang dapat diberikan kepada Notaris dalam menjalankan tugas jabatannya sebagai pejabat umum, hal ini tercermin dalam Pasal 66 ayat (1) UUJN

Pemanggilan Notaris oleh penyidik, penuntut umum, maupun hakim untuk hadir dalam pemeriksaan suatu perkara, baik perdata, pidana maupun tata usaha Negara yang tidak berkaitan langsung dengan akta yang dibuat Notaris tidak memerlukan persetujuan dari MKN. Dalam pemahaman perlindungan hukum terhadap Notaris yang tercantum dalam Pasal 66 UUJN$\mathrm{P}$ ini harus termasuk di dalamnya Notaris pengganti, Pejabat Sementara Notaris dan Notaris emeritus atau werda Notaris, karena dalam praktek masih sering dilakukan pemanggilan (pemeriksaan) kepada Notaris yang sudah berhenti menjabat sebagai Notaris untuk diperiksa oleh penyidik terkait dengan akta-akta yang pernah dibuatnya semasa masih menjabat sebagai Notaris. Diharapkan dengan adanya UUJN-P ini keberadaan MKN dapat memberikan perlindungan hukum bagi semua orang yang (pernah) menjalankan tugas jabatan sebagai Notaris. 


\section{Prosedur Penangaan Perkara Terhadap Jabatan Notaris Jika Akta yang dibuat Terbukti sebagai tindak pidana}

Prosedur penanganan yang dilakukan oleh lembaga perlindungan hukum terhadap jabatan Notaris, yaitu pada masa sebelum berlakunya UUJNP, yaitu yang dilakukan oleh MPD dan pada masa setelah berlakunya UUJN$\mathrm{P}$, yang dilakukan oleh MKN. Berikut akan dibahas mengenai perbandingan penanganan yang dilakukan oleh masing-masing lembaga tersebut dalam memberikan perlindungan hukum terhadap jabatan Notaris, yang akan diuraikan sebagai berikut.

Perlindungan hukum terhadap jabatan Notaris awalnya dilakukan oleh MPD. Kewenangan MPD tersebut adalah dalam hal memberikan atau menolak permintaan persetujuan dari penyidik yang hendak memanggil Notaris guna kepentingan pemeriksaan terkait dengan akta yang dibuat oleh atau dihadapan Notaris (Pasal 66 ayat (1) UUJN). Kewengan ini merupakan kewenangan khusus (mutlak) yang hanya dimiliki oleh MPD, dan tidak dimiliki oleh lembaga lainnya (MPW, dan MPP).

Berdasarkan Pasal 66 ayat (1) UUJN tersebut, maka polisi, jaksa maupun hakim yang hendak memanggil Notaris untuk diperiksa harus mendapat persetujuan terlebih dahulu dari MPD, karena tanpa adanya persetujuan dari MPD, maka penyidik tidak dapat secara langsung memanggil atau memeriksa Notaris tersebut. Dalam memberikan perlindungan hukum, MPD wajib patuh terhadap aturan hukum yang berlaku, dalam hal tata cara penanganan serta prosedur pemanggilan Notaris yang telah diatur dalam Peraturan Menteri Hukum dan HAM RI Nomor M.03.HT.10. Tahun 2007 tentang Pengambilan Minuta Akta dan Pemanggilan Notaris.

Apabila terdapat Notaris yang diduga telah melakukan pelanggaran pidana terkait dengan akta yang dibuatnya, maka penyidik yang hendak memanggil Notaris tersebut harus mengajukan permohonan persetujuan terlebih dahulu kepada MPD, dan dalam hal ini MPD berwenang terlebih 
dahulu mengadakan sidang untuk melakukan pemeriksaan terhadap Notaris tersebut. Dalam sidang tersebut, Notaris akan diperiksa terkait dengan dugaan pelanggaran pidana yang telah dilakukannya terkait dengan akta yang dibuatnya. Apabila MPD menemukan bukti yang kuat terkait dengan pelanggaran yang dilakukan oleh Notaris, maka MPD dapat memutuskan agar Notaris tersebut untuk dieriksa oleh penyidik, kejaksaan atau di pengadilan sebagai implementasi dari ketentuan Pasal 66 ayat (1) UUJN.

Kewenangan MPD sebagaimana yang diatur dalam Pasal 66 ayat (1) UUJN, kini telah dinyatakan tidak berlaku lagi berdasarkan Putusan Mahkamah Konstitusi Nomor 49/PUU-X/2012, dan ketentuan tersebut dinyatakan tidak mempunyai kekuatan hukum mengikat. Dianulirnya ketentuan tersebut, maka pada waktu itu terjadi kekosongan lembaga perlindungan hukum bagi Notaris, sehingga pada saat itu apabila ada Notaris yang diduga melakukan pelanggaran terkait dengan akta yang dibuatnya, maka penyidik dapat langsung memanggil dan memeriksa Notaris tersebut tanpa harus mendapat persetujuan dari MPD lagi.

Dalam mengisi kekosongan tersebut, maka pemerintah segera menetapkan perubahan UUJN yang baru dengan salah satunya membentuk lembaga perlindungan hukum yang baru bagi Notaris, yaitu MKN. UUJN-P telah memberikan suatu bentuk perlindungan hukum secara khusus bagi Notaris, yang diatur dalam Pasal 66 ayat (1) UUJN-P,

Notaris Pengganti, Pejabat Sementara Notaris, emeritus Notaris atau werda Notaris oleh Pasal 322 ayat (1) KUHP tetap mewajibkan merahasiakan isi akta dan keterangan yang diperoleh berkaitan dengan akta-akta yang dibuatnya. Dalam hal ini perlu ditegaskan dalam UUJN-P bahwa keberadaan Notaris, Notaris Pengganti, Pejabat Sementara Notaris, serta emeritus Notaris, berhak memperoleh perlindungan hukum dari MKN terkait dengan adanya dugaan malpraktek dalam proses pembuatan akta otentik. Apabila penyidik hendak memanggil dan memeriksa 
Keberadaan MKN ini, diharapkan dapat memberikan kontribusi hukum yang optimal bagi institusi Notaris dalam menjalankan tugasnya sebagai lembaga perlindungan hukum. Mengenai pengaturan tentang kedudukan serta bentuk perlindungan hukum dari MKN ini sebetulnya belum diatur secara tegas dalam UUJN-P maupun dalam bentuk peraturan perundang-undangan yang lain. Semestinya, setelah diundangkannya UUJN-P tersebut, maka pemerintah harus segera menetapkan Peraturan Menteri maupun Keputusan Menteri Hukum dan Hak Asasi Manusia Republik Indonesia mengenai pedoman pelaksanaan tugas dan kewenangan dari MKN tersebut, mengingat MKN telah dibentuk dan keberadaannya telah ditegaskan dalam UUJN-P. Dalam hal ini seolah-olah keberadaan MKN sebagai lembaga perlindungan hukum bagi Notaris belum dapat menjalankan fungsinya sebagaimana yang diharapkan.

Kewenangan dari MPD tersebut tersebut kini telah menjadi kewenangan MKN, sehingga dalam hal ini untuk mengoptimalkan fungsi atau peran dari MKN ini apabila terjadi kasus dalam dunia kenotarisan yang terkait dengan pemanggilan Notaris oleh penyidik yang notabene harus mendapatkan persetujuan dari MKN, maka dalam hal ini MKN dapat menggunakan prosedur penanganan yang sama seperti MPD. Hal ini dilakukan guna mempertegas keberadaan lembaga $\mathrm{MKN}$ ini sebagai lembaga perlindungan hukum bagi jabatan Notaris.

Kedudukan MKN dalam memberikan suatu perlindungan hukum bagi Notaris merupakan suatu lembaga yang bersifat independen, karena dalam hal ini keberadaan MKN tidak merupakan sub bagian dari pemerintah yang mengangkatnya. MKN dalam menjalankan kewenangannya mengeluarkan suatu keputusan tidak dipengaruhi oleh pihak atau lembaga lainnya, sehingga dalam hal ini keputusan yang dihasilkan oleh MKN ini tidak dapat diganggu gugat. 


\section{PENUTUP}

\section{Kesimpulan}

Tanggung jawab notaris terhadap akta yang dibuat apabila dikemudian hari ternyata terbukti sebagai alat pencucian uang adalah Notaris wajib mempertanggungjawabkan perbuatannya dengan dijatuhi sanksi perdata berupa penggantian biaya atau ganti rugi kepada pihak yang dirugikan atas perbuatan melawan hukum yang dilakukan oleh Notaris. Namun sebelum Notaris dijatuhi sanksi perdata maka Notaris terlebih dahulu harus dapat dibuktikan bahwa telah adanya kerugian yang ditimbulkan dari perbuatan melawan hukum Notaris terhadap para pihak, dan antara kerugian yang diderita dan perbuatan melawan hukum dari Notaris terdapat hubungan kausal, serta perbuatan melawan hukum atau kelalaian tersebut disebabkan kesalahan yang dapat dipertanggungjawabkan kepada Notaris yang bersangkutan.

Perlindungan hukum bagi notaris terhadap akta otentik yang dibuat apabila dikemudian hari ternyata terbukti sebagai alat pencucian uang adalah adanya Majelis Kehormatan Notaris yang bersifat independen, dalam hal ini keberadaan MKN tidak merupakan sub bagian dari pemerintah yang mengangkatnya. MKN dalam menjalankan kewenangannya mengeluarkan suatu keputusan tidak dipengaruhi oleh pihak atau lembaga lainnya, sehingga dalam hal ini keputusan yang dihasilkan oleh MKN ini tidak dapat diganggu gugat. Peneliti menyarankan, pertama, agar seorang Notaris terhindarkan dari segala resiko baik berupa sanksi maupun pembatalan akta otentik dalam proses pembuatan akta yang mengharuskan Notaris bertanggungjawab secara perdata terhadap akta-akta yang dibuatnya, maka Notaris harus menerapkan prinsip kehati-hatian, lebih teliti dan memiliki itikad baik dalam pembuatan akta otentik serta mematuhi ketentuan hukum yang berlaku dan berlandaskan pada moral dan etika. 


\section{DAFTAR PUSTAKA}

\section{A. Literatur}

Fuady, Munir. Teori Hukum Pembuktian (Pidana dan Perdata), Citra Aditya Bakti, Bandung, 2006.

Hadi, Mudofr. Varia Peradilan Tahun VI Nomor 72, Pembatalan Isi Akta Notaris Dengan Putusan Hakim. 2006

Marzuki, Peter Mahmud. Penelitian Hukum. Jakarta: Kencana Prenada Media Group, 2005.

Whitecross, George Patton, A Text-Book af Jurisprudence, Oxford at the Clarendon Press, second editon, 1953.

Wignyosubroto, Soetandyo Sebuah Pengantar ke Arah Perbincangan tentang Pembinaan Penelitian Hukum dalam Pembangunan Jangka Panjang Tahap II, Jakarta: BPHN Departemen Kehakiman, 1995. 